\title{
Konya Ovası Bölgesi'nde Özel Ekonomi Bölgesi Oluşturulmasına Yönelik GZFT Analizi ve Uzman Görüşlerinin Değerlendirilmesi
}

\author{
Evaluation of SWOT Analysis and Expert Opinions on the Establishment \\ of a Special Economic Zone in the Konya Plain Region
}

\author{
(D) Emre Çakmak, ${ }^{1}$ (D) İsmail Önden, ${ }^{2}$ (D) Mesut Samastı ${ }^{2}$ \\ ${ }^{1}$ Piri Reis Üniversitesi, İstanbul \\ ${ }^{2}$ Türkiye Sanayi Sevk ve İdare Enstitüsü, Kocaeli
}

\section{ÖZ}

Dünya ticaretinde orta ve ileri teknoloji ürünlerinin toplam ticarete oranı hızla artmaktadır. Bu duruma uyum gösterebilme kabiliyeti, gelişen ülke ekonomilerinin başarısını etkileyen önemli faktörlerdendir. Bundan dolayı her ülke dünya ekonomisindeki yerlerini güçlendirebilmek veya koruyabilmek için çeşitli politikalar geliştirmektedirler. Özel ekonomi bölgeleri, ileri teknoloji üretimine yönelimi sağlamaları, etkin yönetim yapıları, lojistik kabiliyetleri ve ARGE altyapıları nedeniyle bu kapsamda önemli bir araç olarak ortaya çıkmaktadır. Konya Ovası bölgesinde de özel ekonomi bölgelerinin kurulmasına yönelik bir istek ve bu konuda çeşitli araştırmalar mevcuttur. Özel ekonomi bölgelerinin (ÖEB) nitelikleri ve kurguları ülkeden ülkeye değiştiğinden, bölgenin güçlü ve zayıf yönlerinin ortaya konulması ilk aşama olarak görülebilir. Bu noktada bölge uzmanlarının görüşlerinin yansıtılması, bölgenin beklentilerinin anlaşılmasında ve bölgeye özel ÖEB kurgusunun yapılabilmesinde önemlidir. Bu gerekçelerden dolayı 129 davetli uzman ile bir çalıştay gerçekleştirilmiş ve Ortak Akıl Platformu adımları ile sistematik şekilde uzmanlarla GZFT analizi gerçekleştirilmiştir. Uzmanlar ile yapılan çaışmanın ilk aşamasında GZFT çalışması gerçekleştirilmiş, ikinci aşamasında ise belirlenen sıkıntılara yönelik öneri geliştirme çalışması gerçekleştirilmiştir. GZFT çalışmasının sonucunda bölgenin konum avantajı, üretim kapasiteleri, maliyet avantajları gibi güçlü ve fırsatlar ortaya çıkmış. Bürokrasi, kurumsallaşma, nitelikli istihdam, limana mesafe gibi başlıkların ise tehdit veya zayıf yön olarak gösterilmiştir. Bu çalışma kapsamında elde edilmiş olan bulgular bölgede kurulması muhtemel olan ÖEB'e yönelik beklentiyi ortaya koymuştur. Bu nedenle, makale çalışması ÖEB ile ilgili bir ön çalışma olarak kurgulanmıştır.

Anahtar sözcükler: Bölgesel kalkınma; GZFT analizi; Konya Ovası bölgesi; özel ekonomi bölgeleri; saha analizi.

\section{ABSTRACT}

The share of medium and high technology products in world trade is increasing rapidly. The ability to adapt to this situation is an important factor affecting the success of developing country economies. Therefore, each country develops various policies to protect its place in the world economy. Special economic zones (SEZ) are important tools in this context due to their orientation towards advanced technology production, effective management qualifications, logistics capabilities and R\&D capabilities. There is also a discussion for the establishment of Special Economic Zones in Konya Region and there are various researches on this subject. Since the characteristics and the structure of special economic zones have changed from country to country, understanding of the strengths and weaknesses of the region can be regarded as the first stage. At this point it is important to reflect the views of the region experts, to understand the expectations of the region, and to make the special SEZ concept for the region. Due to these reasons, a workshop was held with 129 invited experts and a SWOT analysis was conducted with these experts in a systematic manner with the common knowledge platform steps. In the first phase of the workshop, the SWOT study was carried out. In the second phase, solution discussions for the determined problems in the first phase were carried out. As a result of the SWOT study, strong and opportunities such as location advantage, production capacities and cost advantages of the region emerged. Headings such as bureaucracy, institutionalization, lack of qualified employment and distance to the port are shown as threats or weaknesses. The findings obtained in this study revealed the expectation for the SEZ which is likely to be established in the region. For this reason, the article was designed as a preliminary study on SEZ.

Keywords: Regional development; SWOT analysis; Konya Plain region; special economic zones; case analysis.

Geliş tarihi: 03.04.2019 Kabul tarihi: 30.10 .2019

Online yayımlanma tarihi: 19.02.2020

İletişim: Emre Çakmak.

e-posta: ecakmak@pirireis.edu.tr 


\section{Giriş}

Özel Ekonomi Bölgeleri (ÖEB), ülkeler dahilinde coğrafi bölgeleri kapsamaktadır-endüstriyi, üretimi ve ihracata yönelik hizmetleri teşvik etmek için kullanılan arsa alanıdır ve tipik olarak bir ülkenin genel ekonomik kanunlarından daha liberal yasalar ve ekonomi politikaları ile karakterize edilir (Wang 20I3). Bu bölgelerde, bölgelere has kanun ve yönetmeliklere sahip olması, devletin dış ticaret üzerindeki denetim ve vergi uygulamalarının bir kısmından vazgeçmesi ve devletin bu bölgelere daha az müdahale etmesi sayesinde daha serbest ticari faaliyet yapılabilmektedir.

Bu bölgeler literatürde çeşitli özellikleri ile tartışılan, bölgesel kalkınma için kullanılabilecek bir araç olarak tanımlamaktadır. Dünyanın farklı bölgelerinde farklı niteliklerle yer alan özel üretim alanları, özellikle sektörel odaklanma ve ileri teknoloji üretiminin sağlanmasında fayda sağlamaktadırlar. Ancak ÖEB'nin başarılı çalışabilmesi için önemli bazı hususların gözden kaçırılmaması gereklidir. Bölgelerdeki başarının önündeki en yaygın engeller şunlardır: (FIAS 2008)

- Uygun olmayan saha lokasyonu ve yüksek sermaye harcamalarına ihtiyaç duyması

- Rekabetçi olmayan politikalar-geçici vergi indirimlerine güvenme, katı performans gereksinimlerine ve yetersiz iş gücü politikaları ve uygulamaları

- Zayıf bölge geliştirme uygulamaları-uygun olmayan şekilde tasarlanmış veya aşırı tasarlanmış tesisler, yetersiz bakım ve tanıtım uygulamaları

- Sübvanse edilmiş kira ve diğer hizmetler

- Kullanışsız ve hantal prosedürler ve kontroller

- Yetersiz idari yapılanma veya bölge idaresinde çok fazla yapılanmanın olması

- Altyapı geliştirmede özel geliştiriciler ve hükümetler arasinda zayıf bir koordinasyon.

Dünya ihracat verileri dikkate alındığında en fazla ihraç edilen ilk ve ikinci yüz ürün dikkate alındığında bu ürünlerin dünya toplam ihracatının \%85'i gibi bir rakamı oluşturduğu görülebilmektedir (Ricardo ve diğ. 20I I; TÜSSiDE 20I7b). Bir diğer husus ise teknoloji dönüşümünün sağlanmasıdır. Bu noktada ifade edilmiş olan dünyada en fazla ihracatı gerçekleştirilen ilk 200 ürünün çoğunluğunun ileri ve orta düzey teknoloji ürünleri olduğu ihracat kalemlerinin analizi sonucunda görülmektedir (TÜSSIDE 20I7a, 20I7b). Hem teknoloji hem de ölçeğin belirli ürünlerin üretimi sonucunda gerçekleşeceği tespiti, sanayinin tüm ürünleri üretmesi yerine belirli ihracat kalemlerine odaklanmasının gerekliliğini ortaya koymaktadır. ÖEB'n başarılı olabilmesi için bölgedeki kısıtlı kaynakları verimli kullanarak tüm ürünleri üretmeye çalışmak yerine bölgede üretim kabiliyetinin olduğu ve dünyada pazarı olan ürünlere odaklanmalı ve bu ürünler üretilmeye çalışılmalıdır. Dolayısı ile odaklanma ile hem ölçek ile ilgili durumun, hem de teknoloji dönüşümü ile ilgili du- rumların çözülebileceği görülebilmektedir. Bu noktada ilk önce ürünlerin, Türkiye pazarına üretilmesi, ardından da dünya pazarlarına satışın hedeflenmesi, gerekli tecrübenin edinilmesiyle rekabetçiliğin daha rahat sağlanmasını beraberinde getirecektir.

Türkiye'de sanayi altyapısı göz önüne alındığında üretimin ve sanayi altyapısının belirli bölgelerde kümelendiği görülebilmektedir. Bu kümelenmenin en başında Marmara Bölgesi gelmektedir. Marmara bölgesi İstanbul'u merkezine alacak şekilde doğu ve batı aksında yer alan gelişmiş bir sanayi bölgesidir. Bu bölgeden hem ülkenin ihtiyacı karşılanmakta hem de ülkenin ihracatının büyük bölümü gerçekleştirilmektedir. Gayrisafi Yurtiçi Hasıla'nın 2017 verilerine göre Marmara bölgesi Gayrisafi Yurtiçi Hasıla'ya \%47,ı katkı sağlamaktadır. Ekonomiye en büyük katkıyı Gayrisafi Yurtiçi Hasıla'nın \%3।,2 oluşturarak İstanbul yapmaktadır. İstanbul'u sırasıyla \%8,2 ile Ankara ve \%7 ile İzmir takip etmektedir (TUiK 20I7). Bu verilere bakıldığında ülkenin ekonomisine en katkıyı Marmara bölgesi yapmaktadır. Bu durum ülkenin ekonomisinin bir bölgeye sıkıştığını göstermektedir. Bu bölgeye alternatif bölgeler gerek herhangi bir afet gibi olağanüstü bir durum noktasında ortaya çıkabilecek olan riskin havuzlanması, gerekse alternatif bölgelerde de bölgesel kalkınmanın sağlanması açısından gereklidir. Gayrisafi Yurtiçi Hasıla'nın 2017 verilerine göre KOP bölgesi illeri ekonomiye \%3,8 ve bu bölge içinde en büyük katkıуı \%2, I ile Konya yapmaktadır. Konya Ovası Bölgesi (KOP), cari fazla veren ekonomik altyapısı (TÜIK 20I3), sanayi üretim kapasitesi ile bir alternatif bölge olarak ortaya çıkmaktadır.

KOP bölgesinde ÖEB'in oluşturulması ve nitelikli üretimin gerçekleştirilmesine yönelik tartışmalar mevcuttur. Dolayısıyla ÖEB konseptine yönelik bölgeye dönük daha derin araştırmaların yapılması; bu bölgede ÖEB kurgusunun oluşturulması durumunda gerçekleştirilecek olan yatırımın idari/mali, teknik ve teknolojik açılardan gereksinimlerinin ortaya konulması başarılı bir sistemin kurgulanması açısından gereklidir. Bu noktadaki ilk aşama ise bölgenin beklentisinin ortaya konulması, fırsat ve tehditlerinin, güçlü ve zayıf yönlerinin ortaya konulmasıdır. Bölgede yeni bir ÖEB konseptinin kurgulanabilmesi için geçmiş tecrübelerin bulunmaması nedeni ile kalitatif yöntemler izlenerek konu ile ilgili tecrübesi bulunan uzmanların görüşlerinin alınması gereklidir. Bu alanda en sık kullanılan tekniklerin başında ise GZFT analizi gelmektedir. GZFT analizi, problemi değerlendirme konusunda bir çerçeve sunmaktadır. Bu yapı altında da yeni tasarımın olası etkilerinin dört ana başlık altında değerlendirilebilmesi mümkün olabilmektedir.

Çalışma kapsamında bölgede bir ÖEB kurgusu oluşturulmasına yönelik bölge uzmanlarının görüşlerinin tespit edilmesi hedeflenmiştir. Bu nedenle de bölgedeki uzmanların tartışılmakta olan ÖEB konseptine yönelik bölge özelinde değerlendirme yapmaları istenmiştir. GZFT çalışmasının gerçekleştirilmesi için bölgeden özel sektör, kamu, sivil toplum ve akademiden temsilcilerin davet edildiği bir çalıştay düzenlenmiştir. Çalış- 
tay kapsamında ortak akıl platformu adı verilen veri toplama yönteminin adımları izlenmiştir. Ortak akıl platformu uzman katılımcıların fikirlerini belirtmeleri noktasında bir çerçeve önermektedir ve bu sayede uzman görüşleri bir sistem sayesinde toplanarak, tüm katılımcıların net olarak katkıda bulunması sağlanmıştır. Bölgenin ÖEB’e ev sahipliği yapması durumu ile ilgili güçlü ve zayıf yönler ortaya konulmuş, fırsat ve tehditler belirlenmiştir. GZFT çalışmasından sonra ise ortaya çıkması muhtemel olan, tespit edilmiş tehditlere ve fırsatlara yönelik öneri geliştirme çalışması gerçekleştirilmiştir. Bu analizlerin maksadı yüksek beklentileri bulunan bölgenin bir ÖEB kurgusu gerçekleştirilmesine yönelik bölgeyi nasıl gördüğünün tespitinin gerçekleştirilmesi ve bir öngörünün sağlanmasıdır. $\mathrm{Bu}$ bulgular için ise metin madenciliği yöntemleri kullanılmış ve bulgular bu yöntem kabiliyetleri ile sınıflanmıştır.

Makalenin kurgusu ise şu şekilde yapılmıştır. Öncelikle çalışma alanı ve özel ekonomik bölgeleri konsepti tanıtılmaktadır. Ardından bölgede faaliyete alınması planlanan özel ekonomi bölgesi ile ilgili saha analizi bölümü yer almaktadır. Bu bölümde Konya Ovası Bölgesi ile ilgili genel tanımlamalar ve ÖEB'nin faydaları ve beklenen faydalar ile ilgili bulgular verilmektedir. Bu bölümü uygulama bölümü izlemektedir. Bu bölümde öncelikle gerçekleşen saha analizinde kullanılan yöntemlerin neler olduğu ve nasıl kullanıldıkları ifade edilmiş, ardından gerçekleştirilmiş olan veri toplama ve analiz kısımlarına yer verilerek elde edilen bulgular özetlenmiştir. Sonuç ve değerlendirme bölgesi nihai tartışmanın ve sonuçları vermiştir.

\section{2. Çalışma Alanı ve Özel Ekonomi Bölgesi (ÖÉB) Konsepti}

Çalışma kapsamında Türkiye'nin merkezinde bulunan Konya Ovası Bölgesi odak olarak alınmıştır. Bölgede ÖEB'ne yönelik süre gelen çalışmalar ve otomobil gibi odaklanılan üretime yönelik araştırmalar mevcuttur (KOP Bölge Kalkınma İdaresi Başkanlığı 20I2; Protema 2016). Bölge sanayicilerinin ve siyasetçilerinin desteği, bölgenin sanayi altyapısı ve cari fazla veren ekonomisi (TÜBITAK TÜSSIDE 2018) bölgeyi bu yeni konseptin uygulanabilirliği noktasında ön plana çıkartmaktadır. Bölüm kapsamında da bölge ile ilgili genel tanımlama yapılmakta ve çalışma kapsamında dikkate alınmakta olan ÖEB konsepti tanıtılmaktadır.

\section{I. Bölge Özellikleri}

Konya Ovası Projesi (KOP) bölgesi, Konya, Karaman, Aksaray, Niğde, Nevşehir, Kırşehir, Kırıkkale ve Yozgat illerinden oluşan bir bölgedir. Bölge 4 milyonu aşan nüfusu (TÜIK 2016), cari fazlası veren ekonomik yapısı ve Türkiye ortalamasının altındaki işsizlik rakamları ile Türkiye'nin önemli sanayi bölgelerinden tanesidir (TÜSSIDE 20 I7a). Bölge uluslararası ticaretin en önemli çıkış kapısı olan limanlara Mersin Limanları ile ulaşmaktadır. Çıkış kapısının Mersin olmasının nedeni en yakın limanların

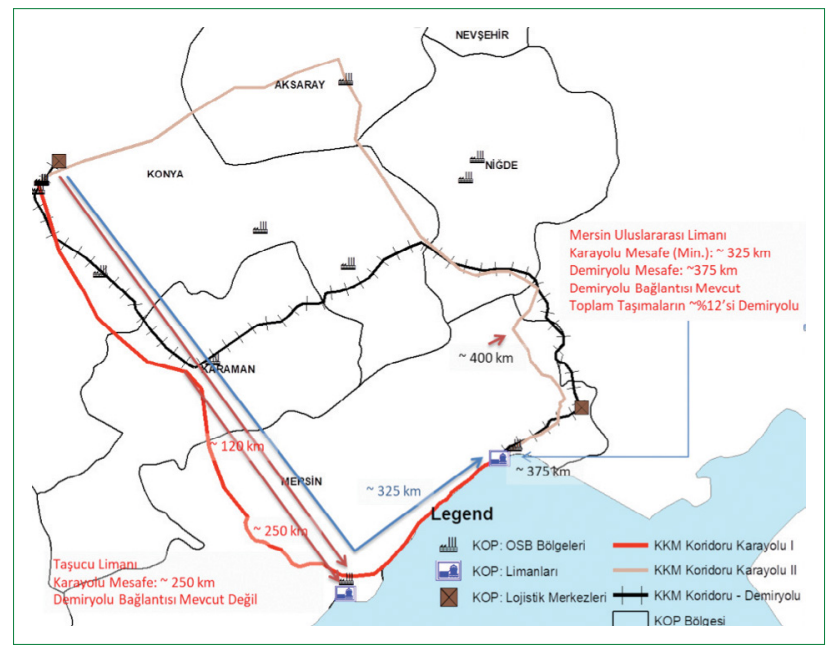

Şekil I. Konya Karaman Mersin ticaret koridoru üretim alanları ve ulaşım özellikleri.

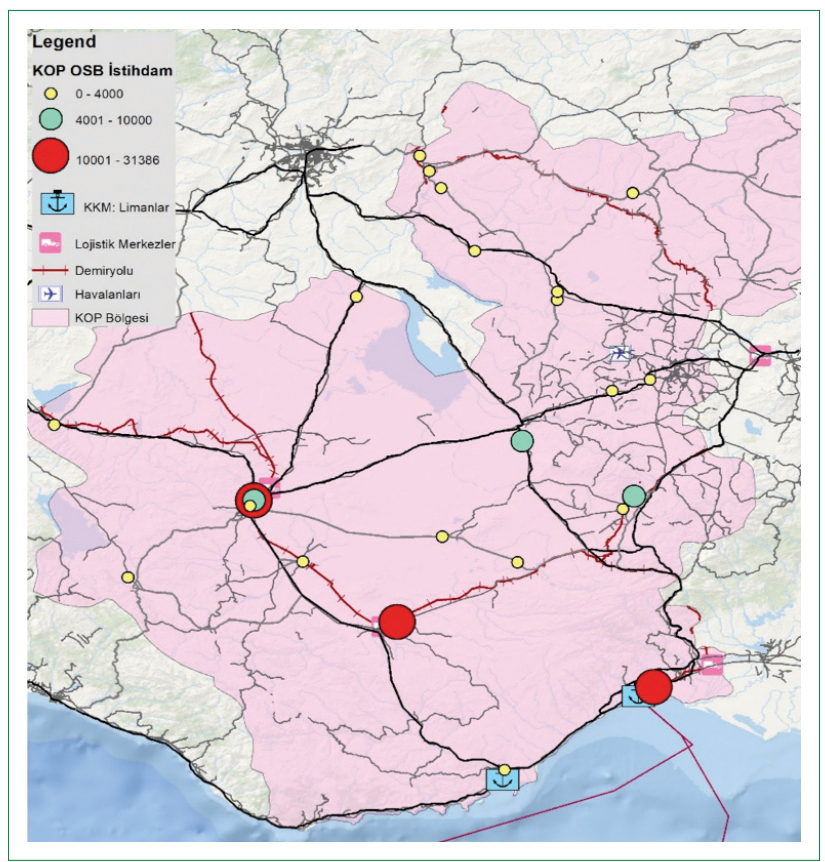

Şekil 2. KOP illeri ve Mersin OSB'lerindeki istihdam sayıları.

Mersin'de bulunması ve lojistik maliyet avantajının sağlanması amacı ile en yakın limanların tercih edilmesinin bir gereklilik olmasıdır. Bölge karayolu ile Mersin International Port ve Taşucu Limanı'na ulaşmaktadır. Demiryolu ile ise Mersin International Port'a erişim mevcuttur. Şekil I, Konya-Karaman-Mersin (KKM) ticaret koridorunun ulaşım yapısını ve limanlar ile üretim merkezleri arasındaki mesafeleri ifade etmektedir.

Bölgedeki üretim merkezleri olan OSB’lerin mekânsal dağılımı ve OSB'lerdeki istihdam oranları Şekil 2'de görsel olarak ifade edilmiştir. Türkiye genelinde ise illerin GSYIH dağılımlarına göre sınıflanması ve bu değerlerin sektörel dağılımları ise Şekil 3'te verilmiştir. 


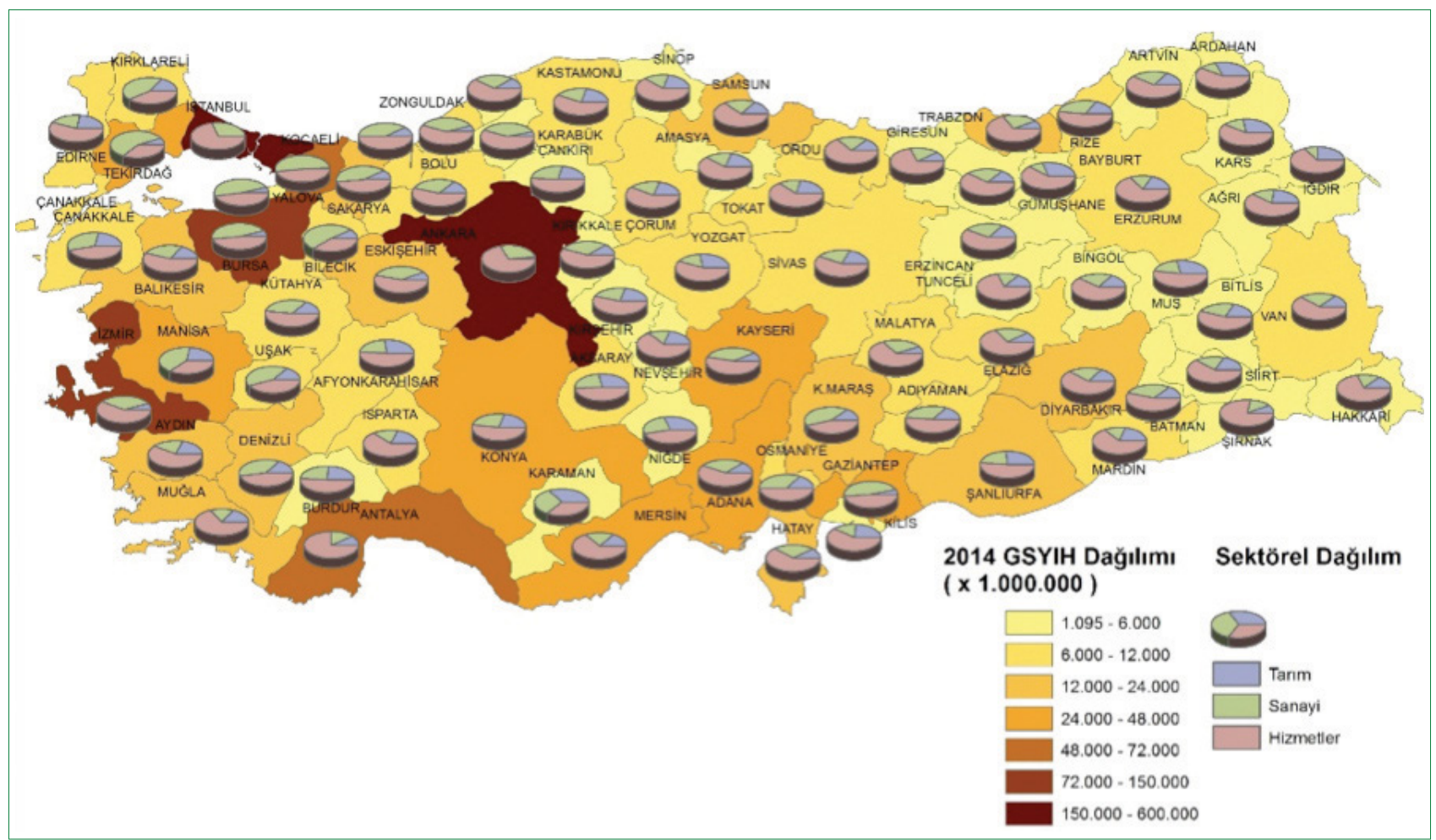

Şekil 3. Türkiye GSYiH sınıfları ve sektörel dağııımları.

KOP Bölgesinin bölgenin sanayisi dikkate alındığında makine sektörü, tarım ve gıda sektörü ön plana çıkmaktadır. Bölgenin dış ticaret verileri incelendiğinde cari fazla verildiği görülmekle birlikte bu verinin teknoloji sınıfları incelendiğinde bölgenin geliştirmesi gerekli olan alanlar ortaya çıkmaktadır. Bölge orta ileri teknoloji üretiminde iyi performans göstermekle birlikte ileri teknoloji üretiminde sınırlı performans göstermekte ve bu alanda cari açık vermektedir. Bölgenin ihracat yaptığı ülkeler listelendiğinde ilk beş sırayı Irak, Almanya, Rusya, Suriye ve İran almaktadır. İthalat yaptığı ülkeler listelendiğinde ise Çin, Rusya, Almanya, İtalya ve Kanada ilk beş sırayı almaktadır (TÜBITAK TÜSSIDE 2018). Ülkelerin gelişmişlik seviyelerine bakıldığında ileri teknoloji alanındaki cari açık görülebilmektedir. Teknoloji seviyelerine göre ihracat verilerine bakıldığında Şekil 4'te verilmektedir. Şekilde I: ileri teknoloji üretimini, 2 orta seviye teknoloji üretimini, 3 düşük seviye teknoloji üretimini, 4 kaynak tabanlı tarımsal üretimi, 5 birincil ürünleri, 6 sınıflanamayan ürünleri ifade etmektedir.

Bölgenin ticaret verileri incelendiğin en fazla ihracat ver ithalat yapılan ürün kalemleri sıra ile Tablo I ve Tablo 2'de verilmiştir.

Bölgenin taşımacılık modlarını tek tek incelediğimizde; bölge, karayolu altyapısı bakımından Türkiye'nin diğer bölgelerinde olduğu gibi geniş bir karayolu ağına sahiptir. Bölgedeki mevcut yolların toplam uzunluğu yaklaşık olarak 85 bin kilometredir (KGM 2016). Diğer bir taşımacılık modu olan demiryolu taşımacılığı da KOP bölgesinde mevcut durumdadır. Yeni tren

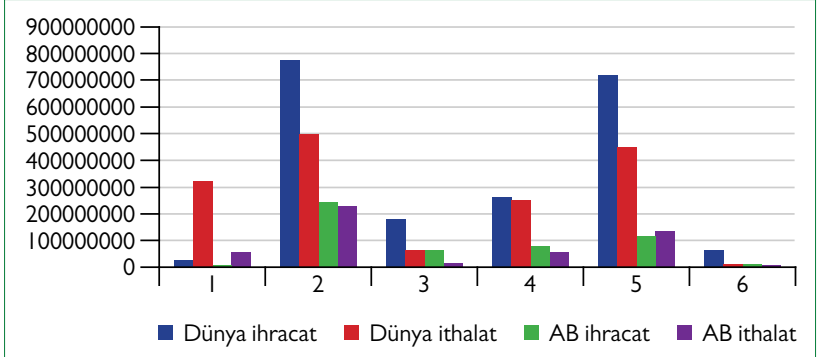

Şekil 4. KOP bölgesi ihracat teknoloji seviyeleri (TÜBITAK TÜSSIDE 20I8).

yolu altyapılarının tamamlanması ile Konya'dan Mersin'e kadar rahatıkla hızlı trenle yük ve yolcu taşımacılığı yapılabilecektir. Bölge ulaşım taşıma altyapılarına ek olarak TCDD tarafından yatırımı gerçekleştirilen lojistik merkezlerden üç tanesi bölgede yer almaktadır (TCDD 20 I7). Konya (Kayacık), Karaman ve Mersin (Yenice) lojistik merkezlerinin inşası devam etmektedir.

Lojistik merkez yatırımları Türkiye'de yer alan lojistik hareketliliğin merkezleri olacağından dolayı bu tesisler Konya-KaramanMersin ticaret koridorunun yük konsolidasyonu ve dağıtımında da merkezleri oluşturacaklardır. Bölge denizyolu bağlantısına bakıldığında, karayolu ile Taşucu Limanı'na, karayolu ve demiryolu ile Mersin Uluslararası Limanı'na erişim sağlamaktadır. Mersin Taşucu'nda yer alan Taşucu Limanı'nın özelleştirme ihalesi gerçekleştirilmiş ve limanın rehabilitasyonu sayesinde bölgede dünya deniz taşımacılık ağına entegre ikinci bir liman oluşacaktır. Liman mevcut durumda da RORO hatları ile ve dökme 
Tablo I. KOP bölgesi illeri ve Mersin'in en fazla ihraç ettiği ürün sınıflarının parasal miktarı

\begin{tabular}{lc}
\hline Ürün açıklaması & Milyon \$ \\
\hline Zencefilli ekmek, tatlı bisküviler, waffle ve gofretler & 167 \\
Kara taşıtlarının diğer aksam-parçaları & 139 \\
Mercimekler; kabuksuz (kuru) & 133 \\
Hububat-baklagilin öğütülmesi, işlenmesi & \\
için makina-cihazlar & 126 \\
Limon ve tatlı limon (taze/kurutulmuş) & 121 \\
Buğday ve mahlut unu & 119 \\
Diğer ekmekçi mamulleri & 104 \\
Mandarin, klemantin, vilking vb. (taze/kurutulmuş) & 96 \\
Diğer taşıtlar için, zikzag vb özel taban desenli dış lastik & 87 \\
Diğer çikolata, kakao ihtiva eden gıda müstahzarları & 77 \\
Portakal (taze/kurutulmuş) & 71 \\
Makarna & 71 \\
Ayçiçeği tohumu yağları (diğer) & 61 \\
Kuş/kümes hayvanlarının yumurtaları-kabuklu & \\
/taze/pişirilmiş & 56 \\
\hline
\end{tabular}

Tablo 2. KOP illeri ve Mersin ilinde 2015 yilında 50 milyon \$'dan fazla ithalatı gerçekleştirilen ürünler

\begin{tabular}{lc}
\hline Ürün açıklaması & Milyon \$ \\
\hline Mercimekler; kabuksuz (kuru) & 160 \\
Ayçiçeği tohumu yağları; ham & 155 \\
Diğer buğday ve mahlut & 133 \\
Hafif yağ-motor ve uçak benzini & 75 \\
Susam tohumu & 72 \\
Polietilen; özgül kütlesi 0, 94 veya daha fazla olan & 63 \\
Soya fasulyesi & 58 \\
Işığa duyarlı yarı iletken devre elemanları, (led) & 50 \\
\hline
\end{tabular}

yük gemileri ile ticaret koridorunu dünyaya taşımaktadır, ancak limanda konteyner yük taşımacılığı mevcut değildir. Bu bağlantı rotaları yurtdısıına yük gönderilmesi ve yurtdışından yük gelmesi esnasında kullanılacak olan rotalardır. Gelen yükler direk olarak KOP bölgesi ile ilgili olabileceği gibi bu ticari koridor Akdeniz-Marmara; Akdeniz-Karadeniz ve Akdeniz-Orta Anadolu arasında bulunan tüm ticaret koridorlarına temas etmektedir. Bölgede hizmet vermekte olan Konya ve Nevşehir-Kapadokya Havalimanı olmak üzere iki havalimanı da mevcuttur. Bu havaalanlarından yük ve yolcu taşımacilığı yapılabilmektedir.

Şekil 2'de mekânsal dağılımları görülebilen KOP bölgesi ve Mersin ilinin sanayi altyapısına bakacak olursak; bölgede 25 adet OSB (22 karma, 3 ihtisas ve özel OSB), I adet serbest bölge ve 6 adet teknoloji geliştirme bölgesi bu bölgenin sınırları içerisindedir. KOP bölgesindeki tüm ekonomi bölgeleri iller bazında Tablo 3'te gösterilmiştir.
Tablo 3. KOP bölgesi illerindeki ekonomi bölgelerinin sayıları

\begin{tabular}{lcccc}
\hline $\begin{array}{l}\text { KOP bölgesi } \\
\text { illeri }\end{array}$ & $\begin{array}{c}\text { Serbest } \\
\text { bölge }\end{array}$ & $\begin{array}{c}\text { Karma } \\
\text { (OSB) }\end{array}$ & $\begin{array}{c}\text { Ihtisas } \\
\text { (OSB) }\end{array}$ & $\begin{array}{c}\text { Teknoloji geliştirme } \\
\text { bölgesi }\end{array}$ \\
\hline Konya & 0 & 9 & 0 & 2 \\
Karaman & 0 & $\mathrm{I}$ & 0 & 0 \\
Aksaray & 0 & $\mathrm{I}$ & 0 & 0 \\
Niğde & 0 & $\mathrm{I}$ & $\mathrm{I}$ (Deri) & $\mathrm{I}$ \\
Nevşehir & 0 & 2 & 0 & 0 \\
Kırşehir & 0 & 3 & 0 & 0 \\
Kırıkkale & 0 & 2 & $\mathrm{I}($ Silah) & $\mathrm{I}$ \\
Yozgat & 0 & $\mathrm{I}$ & $\mathrm{I}$ (Özel) & $\mathrm{I}$ \\
Mersin & $\mathrm{I}$ & 2 & 0 & $\mathrm{I}$ \\
\hline
\end{tabular}

\section{2. Özel Ekonomi Bölgeleri Konsepti}

Ülkenin geri kalanından farklı idari, düzenleyici ve mali rejimlerle çalışan ve bir ülkedeki coğrafi olarak sınırlandırılmış bir alan içindeki her tür bölgeye "Özel Ekonomi Bölgesi" denmektedir (Dobronogov ve Farole 2012). Bu bölgelerde yurtiçi ekonominin geri kalanına göre farkı yatııı koşulları, vergilendirme ve uluslararası ticaret düzenlemeleri uygulanmaktadır (Dobronogov ve Farole 2012). Günümüz koşullarında yatırım için ayrılan alanların sınırlandırılması ve bu bölge dışında kalan alanların bu bölgelerden sağladığı avantajlardan yararlanılamaması nedeniyle bu tanımlama ÖEB beklentilerin biraz gerisinde kalmaktadır. Daha geniş tanımlama ile özel ekonomi bölgesi, birden fazla il ve ilçeyi kapsayan, belirli bir amaca uygun inşa edilmiş alt bölgelerden oluşan, sanayi altyapısı, teknolojik altyapısı, limanı, havaalanı, meslek okulları ve üniversiteleri, yerleşim ve konut alanları, ticaret yapıları, kültür/sanat ve turistik yapıları gibi tesislerden oluşan ve hep birlikte yönetilen, ülkenin geri kalanından farklı idari, düzenleyici ve mali rejimlerle çalışan sınırlandııılmamış bölgelerdir (Çakmak, Önden, ve Samastı 2017).

Özel ekonomi bölgeleri dünyada hem gelişmekte olan ülkeler hem de gelişmiş ülkeler tarafından uygulanan sanayi politikalarından birisidir. Bu bölgeler, ekonomik büyümeyi teşvik eder ve yatırımın gerçekleştirdiği bölgenin rekabet gücünü artırmaya yardımcı olur (Çağlar ve Kurtsal 20 I I). FIAS (2008) (The Multi-donor Investment Climate Advisory Service of The World Bank Group) tarafından hazırlanan rapora göre, dünyada tahmini olarak 135 ülkede yaklaşık 3.000 özel bölge bulunmakta, bu bölgelerde 68 milyon üstünde iş imkanı sağlanmakta ve 500 milyar dolarlık ticaret yapılmaktadır. Özel ekonomi bölgelerinden hükümetler/yerel yönetimler, yerli ve yabancı yatırımcılar/girişimciler fayda sağlamaktadır.

Özel ekonomi bölgelerinin ülke ekonomisi, yerel yönetimler ve hükümetler için faydaları şu şekilde sıralanabilir (Ge 1999, Dobronogov ve Farole 2012); 
- İstihdam yaratılması

- Doğrudan yabancı yatırımların artması

- İhracat büyümesi ve ekonomik çeşitliliğinin sağlanması

- Sektör çeşitliliğinin yükselmesi

- Döviz kazancının artması

- Bölgesel gelişme sağlaması

- Altyapı Tesislerinin gelişmesi

- Devlet gelirlerinin artması

- Doğal kaynakların kullanımının azaltılması (Geri dönüşüm, tekrar kullanma ve etkili imha yöntemleri gibi)

- Ekonomik kalkınma sağlaması

- Siyasi hedefler olarak kullanılması

- Bilginin transfer edilmesi

- Teknolojik yeniliklerin kullanılması ve yayılması

- Uzmanlaşmanın artması

- Maddi olmayan faydalar

Özel ekonomi bölgelerinin yabancı yatırımcılar için faydaları; (UNIDO 20I5, FIAS 2008)

- Düşük maliyetli işgücüne erişim imkanı

- Gümrüksüz ithalat rejimi sağlanması

- Piyasalara kolay erişim imkanı

- Yatırım yapılan ülke pazarındaki rekabet gücünün düşüklügünden sağlanan avantajlar

- Dikey entegrasyonun artması

- Ürün yaşam döngüsünün uzatması

Özel ekonomi bölgelerinin yerel yatırımcılar ve girişimciler için faydaları; (UNIDO 20I5)

- Gümrüksüz ürün ve hizmet satışı imkanı

- Özel teşviklerden yararlanma

- Uluslararası rekabet gücünün artması

- Hem yatırım yapılan ülkedeki hem de diğer ülkelerdeki pazarlara aynı anda ticaretin olması

Özel ekonomi bölgelerinin ülke ekonomisi, yerel yönetimler ve hükümetler için faydaları yukarı sıralanmıştır. Ancak, bu bölgelerin bölge halkına, çevreye ve ekonomiye zararları da bulunmaktadır. Bu potansiyel zararlar (Kumar 2008);

- Büyük ölçekli ve haksız arazi temin edilmesi

- Yerleşim ve rehabilitasyon politikaları ve planlarının yetersiz kalması

- Yerel halk için ÖEB nedeniyle ortaya çıkan geçim kaybını önlemede yeni istihdam alanlarının sağlanmaması

- Doğal kaynaklar ve çevre üzerindeki yükün arttırılması ve yerel toplulukların bu kaynaklar fayda sağlayamamaları

- Emlak patlamasına katkıda bulunması ve emlak bölgeleri oluşturması

- Ağır sübvansiyondan kaynaklanan ekonomide potansiyel gelir kaybı

- Onaylama ve uygulama süreciyle ilgili endişeler (yerel yönetim danışma ve yaptırım sınırlarının belirsizliği)

- Yerel halk ile çoğunlukla istişare edilmemesi

- Su güvenliğinin tehdit edilmesi
- Yerel yönetimleri atlanması ve yerel toplulukları görmezden gelinmesi

- Bölgesel eşitsizliklerinin arttırılması

\section{Uygulama ve Bulgular}

Bu bölümde araştırma adımlarının nasıl tasarlandığını, nasıl uygulandığını ve uygulama sonucunda elde edilmiş bulguları verilmiştir. Bölüm kapsamında öncelikle kullanılmış olan araştırma yöntemleri ile ilgili bilgiler ve analiz adımları verilmektedir. Ardından saha araştırmasında görüşü alınan uzmanların kimler olduğu ve katılımcı profili verilmektedir. Uzmanların tanıtılmasından sonra GZFT analizi, öneri geliştirme ve önceliklendirme çalışmasının sonuçları verilmektedir.

\section{I. Çalışmada Kullanılan Yöntem ve GZFT Analizi}

Veri analizi kalitatif veya kantitatif araçlarla yapılabilmektedir. Analiz edilecek problem ile ilgili veri setlerinin bulunması durumunda çeşitli istatistiki veya optimizasyon yöntemlerini kullanılarak gelecek ile ilgili projeksiyon yapma şansı doğmaktadır. Ancak geçmiş verilerin bulunmadığı ve ÖEB gibi yeni bir konsept tartışmasında konu ile ilgili çeşitli tecrübeleri olan uzmanlara başvurmak gereklidir. Bu durumda da kalitatif çeşitli araçlar gündeme gelmektedir.

Uzmanların yeni alanlar ile ilgili tecrübelerini ve görüşlerini yansıtabilmek için ihtiyaca yönelik çeşitli yaklaşımlar üretilmiştir. Bunlardan ilki Delphi yöntemidir. Delphi yöntemi bir konu ile ilgili tartışmada insanların ünvanları ve baskınlıklarının ortadan kalkması için değerlendirmeye katılanların isimleri ve ünvanlarını dikkate almadan yapılan değerlendirme yöntemidir. Yöntem sıra ile insan görüşlerini posta, e-mail gibi araçlarla toplayarak bir moderatör yönetiminde görüşleri tartıştırır. İnsanların ünvanları ve kimlikleri gizli tutulabildiğinden insanlar görüşlerini kolaylıkla ortaya koyabilmekte ve iyileştirme önerileri geliştirilebilmektedir (Önden 201 I).

Stratejik planlama ile ilgili bir diğer yöntem ise PESTLE (P-Politik, E-Ekonomik, S-Sosyal, T-Teknolojik, L-Legal, E-Çevre) yöntemidir. PESTLE yöntemi değerlendirilen konuyu altı başlık altında toparlayarak bir değerlendirme sistemi önerir. Bu sayede yeni durum veya strateji ile ilgili bir çerçeve altında genel durum konunun özünden kopmadan belirlenebilmektedir. Literatürde ve uygulamada çok popüler olan bir diğer değerlendirme yöntemi GZFT 'GZFT' analizidir. GZFT analizi, işletmenin sektördeki rakiplerine oranla üstünlük (S) ve zayıflıkları $(\mathrm{W})$ ile işletmenin içinde bulunduğu çevredeki fırsatlar $(O)$ ve tehditleri $(T)$ belirleyen bir analiz sürecidir (Kamilçelebi 20I2). GZFT analizi değerlendirilen bir problem ile ilgili mevcut durum ile gelecek durum arasındaki ilişkinin kurgulanması ve stratejilerin oluşturulabilmesi konusunda işlevsel bir araç olarak ortaya çıkmaktadır. Güçlü ve zayıf yönlerin ortaya konulması mevcut durumu, firsat ve 
tehditler ise gelecekteki durumları ortaya koyabilmektedir. Bu sayede ortaya çıkan boşluk ile ilgili stratejilerin geliştirilebilmesi söz konusu olabilmektedir. İfade edilen yöntemler değerlendirilen problemler ile ilgili bir değerlendirme çerçevesi oluşturmaktadır. GZFT analizi ÖEB konsepti ile ilgili henüz Türkiye'de bir uygulamanın bulunmaması nedeni ile hem mevcut durumun ortaya konulması, hem de gelecekle ilgili değerlendirmelere ihtiyaç duymaktadır. Bu sebepten dolayı GZFT analizinin kullanılması çalışma kapsamında uygun görülmüş ve analizler bu yöntem ile gerçekleştirilmiştir.

Herhangi bir kalitatif yöntem ile uzmanların tecrübelerinden faydalanılması gerektiğinde insanların yaklaşımlarındaki farkIılıklar değerlendirmeleri etkileyebilecek düzeyde olabilir. Bu problemin ortadan kaldırılabilmesi için yüksek katılımın sağlanması ve insan görüşlerinin geneli yansıtabileceği hale getirilmesi gereklidir. Bölgedeki genel algının yansıtılabilmesi için yüksek katılımlı bir toplantının gerçekleştirilmesi ve sistematik olarak bilgi alışverişinin sağlanması hedeflenmiştir. Bilgi alışverişinin sağlanması için çalıştaylar düzenlemiş ve konunun uzmanlarının bir araya getirildiği çalışma toplantıları yapılmıştır (Şekil 5).

Sistematik yaklaşım ile ilgili TÜBITAK TÜssiDE'nin marka tescilli ürünü olan Ortak Akıl Platformu (OAP) kullanılmıştır (TUSSIDE 2016). Şekil I üzerinde, Ortak Akıl Platformu (OAP)'nun adımları ve akışı gösterilmiştir. OAP, GZFT analizinin gerçekleştirilmesi için bir sistem oluşturmaktadır ve kişisel tartışmaların veya sadece belirli konuların tartışılmasının önüne geçilmektedir.

\subsection{Araştırma Katılımcı Profili ve Tanımlayıcı İstatistikler}

Çalıştay ile Konya-Karaman-Mersin koridoru için güçlü/gelişmeye açık yönler ile bu koridoru etkileyen çevresel firsat/ tehditlere ilişkin düşüncelerinin öğrenilmesi, bunun yanı sıra bu koridorun sanayi ve ticaret anlamında daha etkin hale getirilmesi için yapılması gerekenlerle ilgili alanında önde gelen paydaşların görüşlerinin alınması amaçlanmıştır. Düzenlenen çalıştay, "kürsüden anlatma ve toplu dinleme konferansı" şeklinde olmayıp, yaratıcı fikir oluşturma yöntemi olan Ortak Akıl Platformu tekniği kullanılarak, tüm katılımcıların çalışmaların başından sonuna kadar aktif katılımı ile yazılı bilgi ve belge üretmeye yönelik olarak gerçekleştirilmiştir.

Bu amaçla 28.02.2017 tarihinde Konya'da düzenlenen çalıştaya, toplam 164 katılımcı davet edilmiş olup etkinlik 129 katılımcı ile gerçekleştirilmiştir. Etkinliğe davet edilen uzmanların belirlenmesinde konu ile ilgili tecrübelerinin varlığı dikkate alınmıştır. Bu kapsamda uzmanın belirlenmesinde akademik literatürü takip etmesi ve dünya örneklerini bilmesi, bölgedeki üretim yapısı ve yönetim alanındaki tecrübelere sahip olması, bölgedeki kamu yönetimi ile ilgili alanda bilgi ve tecrübe sahipliği yetkinliklerinden bir tanesine sahip olması aranmıştır. $\mathrm{Bu}$ yetkinliklere uyan bölgedeki üretim tesislerinin sahipleri

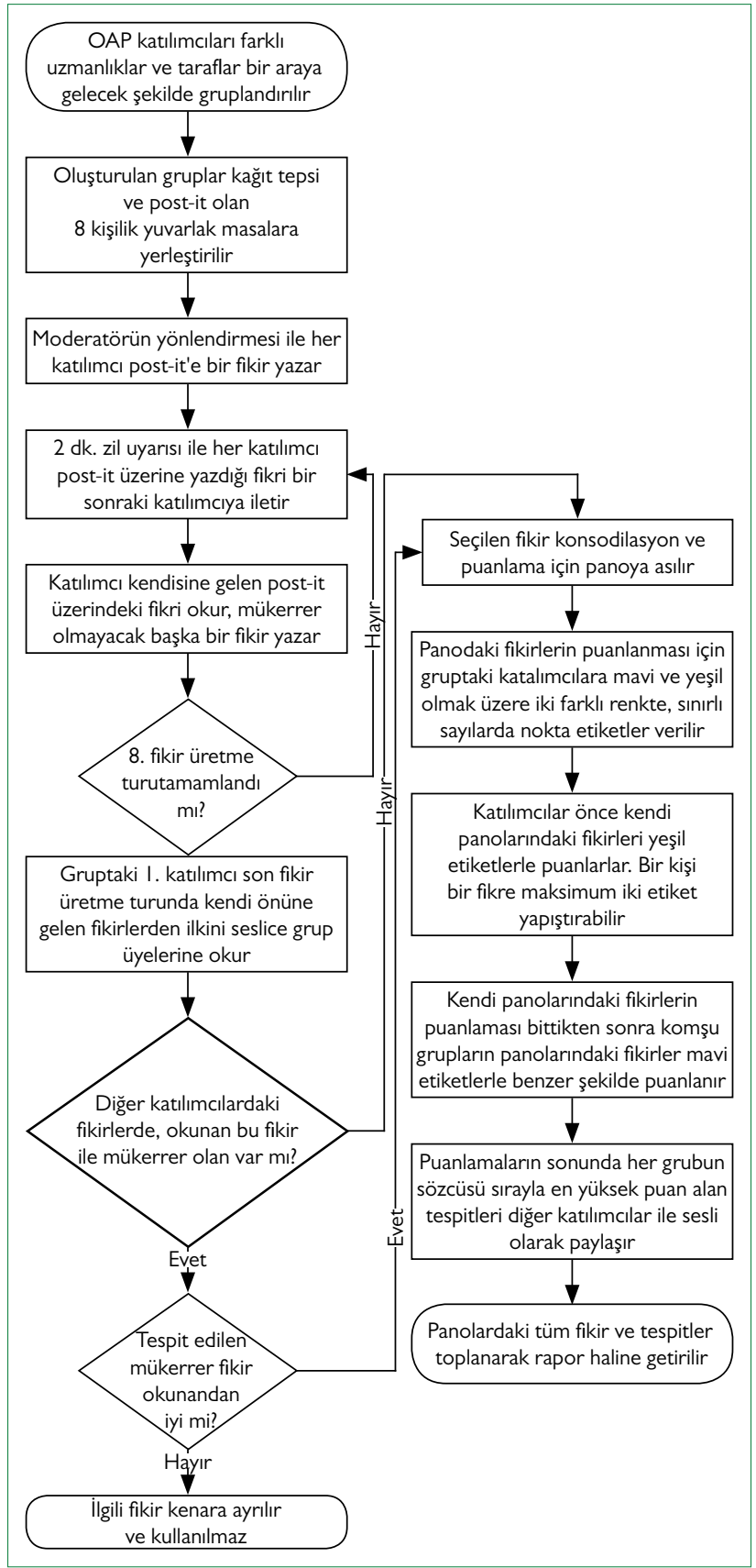

Şekil 5. Ortak Akıl Platformu'nun kullanım yöntemi (Çal ve diğ., 20।7).

veya uzman yöneticileri, lojistik alanında faaliyet gösteren şirketlerin sahipleri veya yöneticileri, sivil toplum kuruluşlarının uzmanları ve yöneticileri, üniversite öğretim elemanları, Teknoloji ve Sanayi Bakanlığı, Gümrük ve Ticaret Bakanlığı, KOP BKI, MEVKA Kalkınma Ajansı, Karayolları, DHMi gibi merkezi ve yerel kamu kurumlarının uzmanları davet edilmiş ve bu kurumların uzmanları çalıştaya katılım göstermiştir.

Katılımcıları ifade etmek amaçlı temsil ettikleri sektörlere göre dört farklı sınıfa ayrılmış ve bu sınıflara düşen katılımcı 


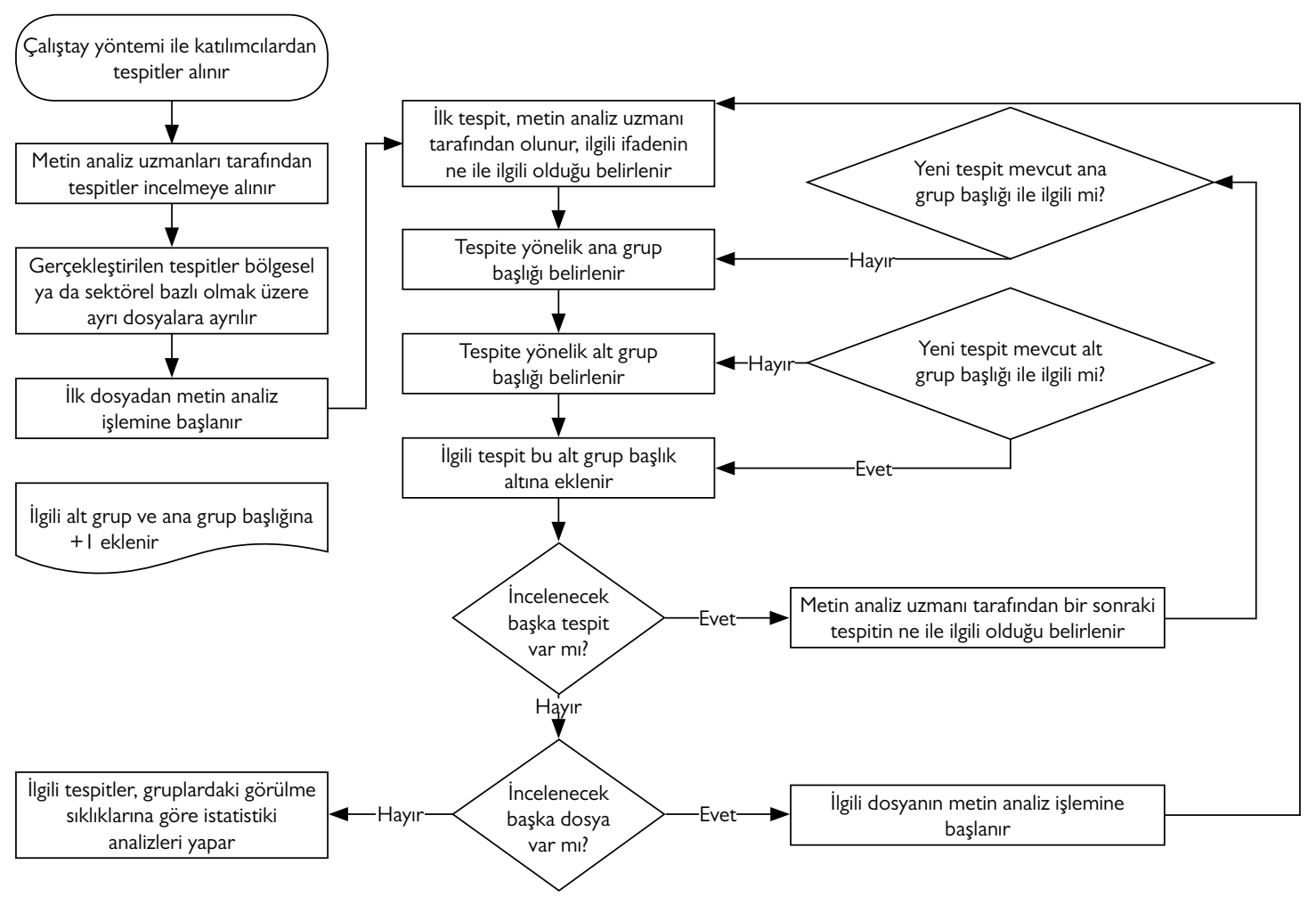

Şekil 6. MAXQDA ile metin analiz yaklaşımı.

sayıları Tablo 4'te verilmiştir. Bu gruplar, kamu kurum/kuruluş temsilcileri, akademisyenler, sivil toplum yetkilileri ve özel sektör temsilcileri olarak belirlenmiştir. Katılımcıların sektörel dağılımı Tablo 4'te gösterilmiştir. Tablo 4'e göre, katılımcıların büyük çoğunluğu kamu kurum/kuruluş temsilcileri olup oranı \%54,3'tür. Diğer gruplar ise \% I ,6'sı sivil toplum yetkilileri, \%।6,3'ü akademisyenler ve \%।7,8'i de özel sektör temsilcilerinden oluşmaktadır.

Katılımcı sayısının yüksek olması ve sağlıklı verilerin katılımcı uzmanlardan edinilebilmesi için katılımcılar 16 çalışma grubuna ayrılmışlardır. 16 grubun 4 tanesi bölgenin zayıf yönleri, 4 tanesi güçlü yanları, 4 tanesi fırsatlarını ve 4 tanesi de tehditlerini çalışmıştır. Oturum planı yukarıda verilen sınıflama mantığında olduğu gibi her masaya farklı uzmanlıkların yansıtılabilmesini sağlamak maksatlı çalışma ekibi tarafından belirlenmiştir.

\subsection{Saha Analizi}

GZFT analizinde, güçlü yönler; Konya-Karaman-Mersin bölgesinin başarılı performans sağlamasını gösteren yetkinlikleri göstermektedir. Zayıf yönler; bu bölgenin başarısını olumsuz etkileyen yetkinlikleri göstermektedir. Fırsatlar; bu bölgenin içinde bulunduğu çevredeki fırsatları göstermektedir. Tehditlerse; fırsatların tam tersi olarak bulunduğu çevredeki bölgeyi etkileyen tehditleri göstermektedir. Çalıştayda uygulanan Or-
Tablo 4. Katılımcı profili

\begin{tabular}{lcc}
\hline Katılımcılar & Sayı & Yüzde \\
\hline Kamu kurum/kuruluş temsilcileri & 70 & 54,3 \\
Sivil toplum yetkilileri & 15 & 11,6 \\
Akademisyenler & 21 & 16,3 \\
Özel sektör temsilcileri & 23 & 17,8 \\
Toplam & 129 & 100,0 \\
\hline
\end{tabular}

tak Akıl Platformu süreci ile Konya-Karaman-Mersin koridorunun mevcut durum analizi için güçlü/gelişmeye açık yönler ile bu koridoru etkileyen firsat/tehditler ortaya konulmuştur.

İlk olarak, Konya-Karaman-Mersin illerinin güçlü yönlerine yönelik çalıştay katılımcılarının belirtmiş oldukları I25 farklı tespitin MaxQDA 12 nitel analiz programı analiz edilmiştir. Bu programa ait analiz yaklaşımı Şekil 6'da gösterilmektedir.

Çalıştay çıktıları ile gerçekleştirilen metin analizleri sonucu tespitler tekrar sıklıklarına göre 3 ana grup altında gruplandırılmıştır. Bu gruplardan bölgenin en güçlü olduğu alanın 66 tekrar sıklığı ile "Sanayi ve Ticari Faaliyetler" olduğu görülmektedir. Bölgede Konya gibi sanayisi gelişmiş illerin olması bu durumu açıklamaktadır. "Sanayi ve ticari Faaliyetler" ana grubunun alt grupları incelendiğinde, "Teşviklere bağlı yatırımın 
cazip olması” 8 tekrar sıklığı, "Güçlü sanayi yapısı”, "Enerjiye ulaşım kolaylığı” ve "Üniversite-sanayi-kurum işbirlikleri” 7’şer tekrar sıklığı, "Rekabet geliştirici yapının olması” ise 6 tekrar sıklığına sahip olduğu analiz sonuçlarından elde edilmiştir. Bu tespitler "Sanayi ve Ticari Faaliyetler" için gerekli ekosistemi destekleyen parametrelerdir.

"Sanayi ve Ticari Faaliyetler" ana grubunu 48 tekrar sıklığı ile "Coğrafi Konumu Avantajı" ana grubu takip etmektedir. Bölgenin sınıra yakın olması, küresel pazara açılması konusunda ciddi avantaj sağladığından bu ana grubunun ikinci en sık tekrar eden grup olarak çıkmasının anlamlı olduğu düşünülmektedir. Bu ana grubun alt grupları incelendiğinde, "Ulaşım olanaklarının olması” I I tekrar sıklığı, "Tedarikçilere ve hammaddeye ulaşım kolaylı̆̆" 7 tekrar sıklığı ve "Yatırım için geniş ve düz arazilerin mevcudiyeti” 6 tekrar sıklığına sahip olduğu analiz sonuçlarından elde edilmiştir.

Bölgesel Güçlü Yanlar kapsamında yapılan analizlerde son ana grubu olarak II tekrar sıklığı ile "İstihdam Olanakları" takip etmektedir. Bu ana grubun alt grupları incelendiğinde ise "istihdam kolaylığı” ve "Nitelikli personel bulma kolaylığı” 3’er tekrar sıklığı, "Eğitimli ve Nitelikli Yönetici varlığı” ve "Ucuz işgücü” ise 2'şer tekrar sıklığına sahip olduğu analiz sonuçlarından elde edilmiştir.

Bölgenin geliştirilmeye açık olduğu zayıf alanları incelendiğinde ise 127 tespit ortaya konulmuştur. Bu tespitlerin ana gruplandırmaları yapıldığında 30 tekrar sayısı ile "Kurumlar arası Etkin iletişim ve İşbirliği” öncelikli olarak çıkmaktadır. Bu ana grubun altında ise "Akademik işbirliğinin yeterli olmaması" ve “işbirliğinin yeterli olmaması” 6'şar tekrar sıklığına sahipken, “Etkin iletişim eksikliği” "nin 5 tekrar sıklığına sahip olduğu analiz sonuçlarından elde edilmiştir. Bu tespitlerin kök nedeninde işletmeler ve kurumlar arasında etkin iletişim eksiliğinden kaynaklandığı düşünülmektedir.

Bölgenin geliştirilmeye açık olduğu zayıf alanları kapsamında bir sonraki en sık tekrar oranına sahip tespit 22 tekrar ile "Üretim Potansiyelindeki Engeller" tespitidir. Bu ana grubun altındaki tespitler incelendiğinde "Katma değerli üretimin yeterli olmaması” 4 tekrar sıklı̆̆ı, "ürün çeşitliliğinin yeterli olmaması”, “Kaynakların verimsiz kullanılması”, “Ar-Ge faaliyetlerinin yeterli olmaması", "Tarım faaliyetlerinin bilinçsiz yapılması" ve "Küresel pazarlara entegre olamama” tespitlerinin 3'er tekrar sıklığına sahip olduğu görülmektedir. KOP Bölgesi'nde 2016 yılında gerçekleştirilen ithalat ve ihracat verilerine bakıldığında, ihracatın \%37'ü birincil ürün, \%40'unun ise orta teknoloji ürünler olması yapılan tespitlerin doğru olduğunu göstermektedir.

Bölgenin geliştirilmeye açık olduğu zayıf alanları kapsamında bir sonraki en sık tekrar oranına sahip tespit ise 2l tekrar

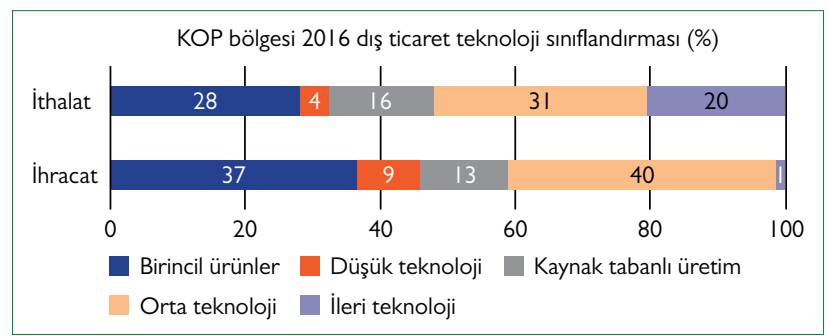

Şekil 7. KOP bölgesi 2016 dış ticaret teknoloji sınıflandırması (KOPBKi, 20।6).

ile "Ulaştırma ve Lojistik" tespiti takip etmektedir. Bu tespite yönelik alt gruplarda ise "Ulaşım entegrasyon ve altyapı olanaklarının geliştirilmesi” I7 tekrar sıklığına sahip olduğu görülmektedir. Dünyada üretilen her I doların 25 cent'i lojistik faaliyetlere harcandığı bilinmektedir (Tokay, Deran, \& Arslan, 2016). Bundan dolayı bölgedeki firmalar, lojistik altyapı olanaklarının geliştirilmesi ile birlikte küresel rekabet ortamında ciddi avantajlar elde edeceklerdir. Bölge'de yapılacak olan Lojistik Köy ile bu entegrasyonların daha etkin yapılması planlanmaktadır (Şekil 7).

Bölgenin sahip olduğu fırsatlar incelendiğinde uzmanlar tarafından I40 farklı tespit ortaya konulmuştur. Benzer şekilde gruplandırılan bu tespitlerden "Üretim Fırsatları" 50 tekrar sayısı ile öncelikli fırsat ana grubu olarak öne çıkmaktadır. "Lojistik Olanaklar" ve "Bölgesel Fırsatlar" ise sırasıyla 27 ve 20 tekrar sıklıklarına sahiptirler. Alt gruplardaki tekrar sıklıklarına bakıldığında "Üretim Fırsatları" ana grubunun alt gruplarında “ihtisas OSB yaklaşımının yaygınlaşması” ve "Bölgedeki tarım ürünleri işlenerek katma değer oluşturulması” ifadelerinin 9 tekrar sıklığı, "Bölgedeki tarımsal hammadde bolluğu" ise 8 tekrar sıklığına sahip olduğu görülmüştür. "Lojistik Olanaklar” ana grubun alt grubunda ise "Ulaşım altyapı olanakları" 10 tekrar sıklığı ve "Diğer lojistik modların etkin olması" ifadeler 8 tekrar sıklığına sahip olduğu analiz sonuçlarından elde edilmiştir. "Bölgesel Fırsatlar" ana grubunun alt grup başlıklarında ise "Bölgenin Üretim için Uygun Alana Sahip Olması" ifadesinin 12 tekrar sıklığına sahip olduğu görülmektedir.

Bölgenin sahip olduğu tehdit olguları incelendiğinde ise uzmanlar tarafından 95 farklı tespit ortaya konulmuştur. Bu tespitlerden "Üretim Faaliyetleri" 23 tekrar ile öncelikli ifade olarak çıkmaktadır. "Üretim Faaliyetleri" ana grubunun altındaki alt gruplar incelendiğinde "Bilinçsiz tarımdan kaynaklı oluşan çevresel tehditler" 7 tekrar sıklığı "Teknolojik üretim altyapısının yetersiz oluşu” ise 5 tekrar sıklığına sahip olduğu görülmektedir. Kontrol sulamadan kaynaklı olarak Bölge'de ciddi su ve yapısal problemler olduğu bilinmektedir. Sulama faaliyetlerinin teknolojik altyapı olanaklarıyla yapılması çevresel tehditlerin oluşmasını engelleyecektir.

"Finansal Problemler" ana grubunun alt gruplarında ise "Yanlış ve yetersiz teşvik uygulamaları” 7 tekrar sıklığına, "Ekonomi- 


\begin{tabular}{|c|c|c|}
\hline Kod Sistemi & KOP ÇAlıştay Öneri & TOPLAM \\
\hline > Üretim Faaliyetleri & $\mathrm{a}$ & 52 \\
\hline > Cesviklerin Geliştirilmesi ve Bürokrasinin Yalınlaştrılması & 口 & 51 \\
\hline - Lojistik Altyapı & घ & 34 \\
\hline$>$ Hedef Pazar ve Rekabet & m & 25 \\
\hline$>$ İstihdam & ॥ & 22 \\
\hline C Kurumlar Arası İletişim ve İsbirliği & . & 17 \\
\hline$>$ Kurumsal Yapı & - & 7 \\
\hline$\Sigma$ TOPLAM & 208 & 208 \\
\hline
\end{tabular}

Şekil 8. Geliştirilen önerilerin üst gruplandırmaları.

deki dalgalanmalar" ise 6 tekrar sıklığına sahip olduğu analiz sonucunda elde edilmiştir. Sürdürülebilir rekabet olanakları için ekonomideki dalgalanmaların daha stabil hale getirilerek, gerek teknolojik altyapı gereksinimleri, gerekse finansal daralmalara yönelik teşviklerin yeterli ve doğru seviyelerde kullanılmasına olanak sağlanmalıdır.

Konya-Karaman-Mersin bölgesinin içsel yeteneklerin (güçlü yönler ve zayıf yönleri) ve bölgeyi etkileyen dış etkilerin (fırsatlar ve tehditler) neler olduğu katılımcılar tarafından belirlendikten sonra, katılımcılara bölgenin sanayi ve ticaret kapasitesini artırmak için öneri fikirler üretmeleri istenmiştir. Öneri fikir üretmeleri sonucunda oluşan 208 tespit MaxQDA nitel analiz programı ile analiz edilerek tespitlerin tekrar sıklıkları hesaplanarak bu tespitlerin gruplandırmaları Şekil 8'deki gibi yapılmıştır.

“Üretim Faaliyetleri” kapsamında gruplandırılan 52 ifadenin alt gruplamalarına bakıldığında "Bölgesel Değer Zincirleri Oluşturulmalı” ifadesi I 2 tekrar sıklığı ile öncelikli ifadeler arasında yer almaktadır. "Kaynakların Verimli Kullanılarak Maliyetlerin Düşürülmesi” 9 tekrar sıklığına sahipken, "Teknolojik altyapı ile üretim faaliyetlerinin modernleştirilmesi” ve "Katma Değerli ürün üretimi” önerileri ise 7 tekrar sıklığına sahiptir.

"Üretim Faaliyetleri” öneri grubunun tekrar sıklığı ile hemen hemen eşit değere sahip "Teşviklerin Geliştirilmesi ve Bürokrasinin Yalınlaştırılması” öneri grubundaki önerilerden olan “Ihtisas OSB ve Kümelenmeler Desteklenmeli ve Yaygınlaştırılmalı” önerisi 18 tekrar sayısı ile bu gruptaki en önemli öneri olduğu görülmektedir. Bu öneriyi II tekrar ile "Ar-Ge ve ÜrGe Faaliyetleri Teşvik Edilmeli” ve 8 tekrar sayısı ile "Teşvik Politikaları Yeniden Düzenlenmeli” önerileri takip etmektedir.

Öneri gruplarında 34 öneri ifadesi ile 3. sırasında yer alan "Lojistik Altyapı" grubunun alt öneri ifadeleri incelendiğinde “Entegre Lojistik Hizmeti Sağlayacak Altyapı Olanakları” önerisinin 15 tekrar ile en önemli öneri ifadesi olduğu görülmektedir. Bu öneri ifadesini 6 tekrar sayısı ile "Demiryolu Altyapı Olanakları Geliştirilmeli” önerisi takip etmektedir.

Benzer şekilde diğer öneri grupları da analiz edildiğinde "Hedef Pazar ve Rekabet” grubundaki "Tanıtım Faaliyetleri ve Bölgesel Markalar Çalışmaları” önerisi tekrar sıklığı, “İstihdam” grubundaki "Yetenek ve Yetkinliğin Geliştirilmesi” önerisinin
I4 tekrar sıklığı, "Kurumlar Arası İletişim ve İşbirliği” grubunda yer alan "Kurumlar Arası Etkin İletişim ve işbirliği Olmalı" önerisinin ise II tekrar sıklığına sahip olduğu görülmektedir.

\section{Sonuç ve Değerlendirme}

Çalışma kapsamında KOP bölgesi için ÖEB kurguları ve beklentileri araştırılmıştır. Değerlendirmenin sistematik olarak gerçekleştirilebilmesi için OAP yaklaşımı kullanılmış ve bu yaklaşımla düzenlenen çalıştayda davetli katılımcılarla GZFT analizi gerçekleştirilmiştir. Çalıştaya kamu, sivil toplum, akademi ve özel sektör temsilcileri katılım göstermiş ve çalıştayda farklı uzmanlıklar ve farklı çalışma kültürlerinin bilgi ve birikiminin yansıtılması sağlanmıştır. Dolayısı ile bu saha araştırmasının sonucunun verildiği özet tabloların çeşitli uzmanlıkların ve önemli tecrübelerin özeti olduğu kolaylıkla ifade edilebilecektir. Özellikle ÖEB kurgusunun yapılması esnasında, mevcut durum analizinde ve tehdit algısında bu değerlendirmelerin önemi olacaktır. Çalıştayın çıktılarına bakıldığında bölgenin konum avantajı, üretim kapasiteleri, maliyet avantajları gibi başlıklar öne çıkmaktadır. Bürokrasi, kurumsallaşma, nitelikli istihdam, limana mesafe gibi başlıkların ise tehdit veya zayıf yön olarak öne çıktığı görülmektedir.

Çalıştayda sadece GZFT aşamaları tamamlanmamıştır, KOP bölgesi için öneriler de geliştirilmiştir. Bu öneriler sektörel odaklanma, teşvik ve destek, teknoloji dönüşümü, istihdamın artırılması, lojistik ve taşımacılık kapasitelerinin geliştirilmesi başlıkları altında kümelenmiştir.

ÖEB'nin sunduğu önemli başlıkların bu iyileştirme önerileri ile ilgili olduğu ifade edilebilir. ÖEB üretim alanları olduğu gibi belirli endüstrilerin üzerine kurgulanmaktadırlar. Dolayısı ile üretimin sağlanabilmesi için istihdam olanaklarının ve gerekli üretimin sağlanabilmesi için de eğitim olanaklarının artırılması gerekmektedir. Bu başlıklar da gerek bölgesel kalkınmanın sağlanması, gerekse ülke ekonomisinin canlanmasını sağlayacak niteliktedir.

Gerçekleşen çalışma kapsamında bölgenin güçlü yönleri açısından konum avantajı ve sanayi ve ticari faaliyetleri ortaya çıkmıştır. Gerçekten de bölgenin ticari faaliyetleri göz önüne alındığında bölgenin orta ileri teknoloji ürünlerinin üretimi ve uluslararası ticareti noktasında bölgesel bir oyuncu olduğu görülebilmektedir. Bunda bölgedeki makine sanayiinin varlığı önemlidir. Konya Ovası bölgesinin tarihi geçmişinde de önemli olarak görünen gıda ve tarım ürünlerinin üretimi ise bölgenin günümüzde de üretim kabiliyetinin en önemli olduğu alanı göstermektedir. Dolayısı ile yeni bir üretim konsepti olan ÖEB'lerin tasarımında da katma değerli gıda sanayiinin kurgulanması da bölgenin mevcutta yapmakta olduğuna ek bir katma değerin üretilmesinde önemli olacaktır. Bu noktada ifade edilen duruma detay bir örnek olarak, Karaman'ın Türkiye'de 
en fazla sayıda elma ağacına sahip olması ve bu üretimin gıda sanayiinde değerlendirilmesi örneği verilebilir. Diğer güçlü yönlere bakıldığında bölgede yer alan ulaşım seçeneklerinin varlığı, yatırımda teşvik olanaklarının bulunması, sanayi altyapısının güçlü olması, enerjiye ulaşımın kolaylığı, tedarikçiye ve hammaddeye yakınlık ve ulaşım kolaylı̆̆ı olarak belirlenmiştir. Bu güçlü yönlerin yanında bir bütünün parçalarını oluşturan güvenlik, turizm faaliyetleri, istihdam kolaylığı, üretim çeşitliliği vb. başlıklar da uzmanlar tarafından ifade edilmiştir.

Bölgedeki tehditlere bakıldığında finansal problemler, ulaşım altyapı eksikliği, bilinçsiz tarım üretimi, yanlış ve yetersiz teşvikler en önde gelen tespitler olarak ortaya çıkmaktadır. Bu tespitler ise bölgede daha iyi çalışacak bir uluslararası ticaret sisteminin nasıl kurgulanması gerektiğine yönelik ipuçlarını vermektedir.

Bölgenin üretim için uygun alana sahip olması, ulaşım altyapısı ve çeşitliliği ve bölgenin yakın olduğu Mersin Limanı'nın uluslararası ticaret için önemli bir liman olması, teşvik olanakları, kurumlar arasında etkin iletişimin ve işbirliğinin olması şeklinde bölgenin fırsatları tespit edilmiştir.

Gelişmeye açık başıاılar olarak ulaşım ve entegrasyonun geliştirilmesi, kalifiye eleman mevcudiyeti ile ilgili iki başlık en önemli tespitler olarak diğer tespitler arasından sıyrılmıştır. İşbirliği eksikliği, akademi ile iletişim eksikliği, teşvik olanakların geliştirilmesi, sosyal olanakların yetersiz olması, marka çalışmaları ve pazarlama eksikliği, yönetim danışmanlığı eksikliği, katma değerli üretimin yeterli olmaması gibi önemli diğer tespitler de yer almaktadır.

Yapılan tespitlere bakıldığında bölgedeki ihracatın geliştirilebilmesi için bölgedeki mevcut durumu anlama noktasında önemli bilgiler yer almaktadır. Bölgenin rekabet gücünün artırılabilmesi için ortaya çıkan nitelikli iş gücü temini, ulaşım altyapısının güçlendirilmesi, markalaşma gereği, yönetişim sisteminin ve teknoloji üretimini sağlayabilecek üniversite-sektör iletişimlerinin sağlanması tespitleri çalışma kapsamında uzman görüşmelerinde tespit edilmiştir.

Bu kapsamda bir ÖEB kurgusunda bir genel bir kurgunun yapılması gerekmektedir. Sadece bir üretim alanı olarak ÖEB kurgusunun yapılması bölgede kurulmak istenen sistemi sağlayamayacaktır. Zira, ÖEB'ler üretime ve sanayiye sistematik bir yaklaşım getirmektedir. Bu yeni yaklaşım ÖEB'in sadece bir üretim alanı olarak değil, teknoloji geliştirme, lojistik ile birlikte üretim ve hizmet alanının oluşturulmasından gelmektedir. Ek olarak ÖEB'ler 7/24 yaşayan alanlar olacak şekilde sosyal donatı alanlarına da sahip olacaklardır. Bu sayede bu alanlar sadece mesai saatlerinde çalışan alanlar değil, yaşamın yer aldığı bölgeler olarak oluşturulmaktadır. Sosyal etkinlikle fuarlar, sektörel toplantılar gibi iş hayatı ile ilgili olabileceği gibi şehir

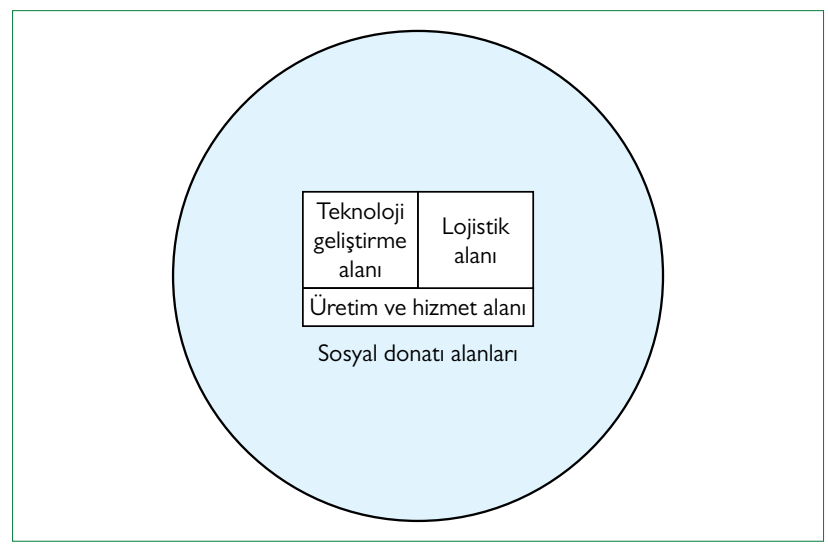

Şekil 9. ÖEB konsepti bileşenleri (TÜBITAK TÜSSIDE 2018).

yaşamı ile ilgili de olabilecektir. Kore'de kurgulanan Incheon ÖEB'i teknoloji üretimini merkezine alan bir şehir olarak kurgulanmıştır. Önerilmekte olan ÖEB konsepti de üretim, ulaşım ile teknoloji üretimini birleştirmekte, aynı zamanda da sosyal hayatı da içerisinde barındırmaktadır. Şekil 9 ise ÖEB konseptinin bileşenlerini ifade etmektedir.

Bunun sonucunda da beklenti anketlerinde tespit edilmiş olan altyapı, teşvik ve hız beklentilerine karşılık verme şansı doğmaktadır. Ek olarak bu bölgelerin aktifleştirilebilmesine yönelik arazi, ekipman \& makine, inşa teşvikleri olduğundan bu alanda da beklentiler karşılanabilecektir. Sonuç olarak bölgesel olarak çekim merkezi olan ve Avrupa Birliği ortak pazarında olan bu bölgeye doğrudan yabancı yatırımı gelmesi de beklenecektir. Bu durum bölgeyi hem Çin'e alternatif bir üretim merkezi haline getirecek hem de bölgeyi beklediği ileri üretim teknolojilerine kavuşturacak bir argüman olarak kullanılabilecektir.

Sanayideki dönüşümlerin gerçekleştirilmesinde bir diğer özellik odaklanmadır. Belirli üretim çıktısı hedefleri ile aynı üretim alanları belirli bölgelerde toplanılarak bir ekosistem oluşturma şansı mevcuttur. Bu noktada ilgili özel ekonomi bölgelerinin şansı Türkiye'nin nüfusu ve alım gücü nedeni ile önemli bir pazar olmasıdır. Belirli sektörlerdeki alım garantisinin verilmesi sonucunda özel ekonomi bölgeleri kurulum aşamasında yüksek rekabet ile boğuşmak zorunda kalmayacaklardır. Ardından belirli tecrübe elde edildikten sonra ise bu ÖEB, KOP bölgesinin etki alanında bulunan pazarlarda da söz sahibi olabileceklerdir. Odaklanma sonucunda elde edilecek en önemli avantaj ölçek avantajıdır. Toplu satın alma, pazarlama, R\&D, servis hizmetlerinin sunulması sonucunda da maliyetler önemli seviyede düşebilecektir. Bu durumda bölgede yer alan şirketler için yüksek rekabetçilik avantajını ifade edecektir. 


\section{KAYNAKLAR}

Çağlar, Esen, ve Yaprak Kurtsal. 2011.“Bölgesel Sanayi Politikası Aracı Olarak Özel Ekonomik Bölgeler: Türkiye'de Organize Sanayi Bölgelerinin Etkileri ve Yetkiler." In 5. Bölgesel Kalkınma ve Yönetişim Sempozyumu Sanayi Politikasının Yönetişimi, Ankara: tepav, 187-201.

Çakmak, Emre, İsmail Önden, ve Mesut Samast1. 2017. “Türkiyédeki Ve Dünyadaki Özel Bölgeler Ve Özel Ekonomi Bölgesi Oluşturulması İçin Dönüşüm Önerileri." In 6. Ulusal Lojistik ve Tedarik Zinciri Kongresi, Antalya, 599-617.

Çal, Murat, İsmail Önden, Mesut Samastı, ve Fahrettin Eldemir. 2017. “Istanbul Traffic Problem: Expert Opinions." In $13^{\text {th }}$ International Strategic Management Conference, Podgorica, Montenegro.

Dobronogov, Anton, ve Thomas Farole. 2012. "An Economic Integration Zone for the East African Community: Exploiting Regional Potential and Addressing Commitment Challenges." Policy Research Working Paper WPS 5967 (February).

FIAS. 2008. "Special Economic Zones." Special Economic Zones Performance, Lessons Learned, and Implications for Zone Development.

Ge, W. 1999. Special Economic Zones and the Economic Transition in China. $5^{\text {th }}$ ed. World scientific.

Hausmann, R., Hidalgo, C. A., Bustos, S., Coscia, M., Simoes, A., \& Yildirim, M. A. 2011. Mapping Paths to Prosperity The Atlas of Economic Complexity.

Kamilçelebi, Hatime. 2012. “Türkiyéde Sigorta Sektörünün GZFT Analizi ve Bir Araştırma.” Ekonomi Bilimleri Dergisi 4(1): 45-54.

KGM. 2016. “Karayollar1 Genel Müdürlügüu.” www.kgm.gov.tr (June 20, 2012).

KOP Bölge Kalkınma İdaresi Başkanlığı. 2012. Özel Ekonomi Bölgesi Ön Çalşsma Raporu İç Anadolu-Akdeniz Özel Ekonomi Koridoru.

Kumar, Shashi. 2008. "SEZs in India: Concept, Objectives and Strategies.": 1-19.

Önden, İsmail. 2011."Mağaza Yeri Seçimi Problemine Coğrafi Bilgi Sistemleri Tabanlı Bir Çözüm Yaklaşımı ve Uygulamasıı.” Yıldız Teknik Üniversitesi.

Protema. 2016. Konyáda Otomobil Üretilebilirliği Fizibilite Raporu. Konya.

TCDD. 2017. “TCDD Türkiye Cumhuriyeti Devlet Demiryolları." http:// www.tcdd.gov.tr/content/100 (March 20, 2018).

TÜBİTAK TÜSSIDE. 2018. Konya-Karaman-Mersin Sanayi ve Ticaret Koridoru Oluşturulmasına Yönelik Etüd ve Fizibilite Projesi Final Raporu. Gebze-Kocaeli.

TUIK. 2017. “İktisadi Faaliyet Kollarına Göre Cari Fiyatlarla Gayrisafi Yurtiçi Hasila."

TÜIK. 2016. "Adrese Dayalı Nüfus Sisteminden Elde Edilen Il Bazlı Nüfus Bilgileri,"

TÜIK. 2013.“íl Bazlı Toplam İthalat Miktarları.”

TUSSIDE. 2016. "Common Intellectual Platform (OAP) Workshop Approach." http://tusside.tubitak.gov.tr/tr/yontemlerimiz/Calistay-YonetimiOAP.

TÜSSIDE. 2017a. Konya Karaman Mersin Ticaret ve Sanayi Koridoru Oluş. turulmasına Yönelik Etüd ve Fizibilite Projesi - Özel Ekonomi Bölgeleri ve Konum Analizleri. Gebze-Kocaeli.

UNIDO. 2015. Economic Zones in the Asean: Industrial Parks, Special Economic Zones, Eco Industrial Parks, Innovation Districts as Strategies for Industrial Competitiveness.

Wang, Jin. 2013. "The Economic Impact of Special Economic Zones: Evidence from Chinese Municipalities." Journal of Development Economics 101(March 2013): 133-47. 